\title{
Morphological Spectrum of Ovarian Teratomas: A 6 Years Experience at a Specialized Diagnostic Institute
}

Fatima Khalid, Sameen Afzal, Ghazi Zafar, Anila Chughtai, Samina Zaman, Akhtar Sohail Chughtai

Department of Histopathology, Chughtai Institute of Pathology, Lahore

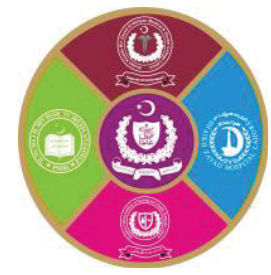

\begin{abstract}
Introduction: Ovarian teratomas include mature cystic teratoma (MCT), immature teratoma (IT) and monodermal teratoma (MoT). Malignant transformation (MT) can occur in MCT and MoT, which remains a diagnostic challenge.

Aims \& Objectives: To discuss the morphological spectrum of ovarian teratomas reported during the last six years at our specialized diagnostic institute and determine the frequency of MT in MCT and MoT.

Place and duration of study: The study was carried out at Chughtai Institute of Pathology from January 2015 to December 2020.

Material \& Methods: A retrospective study was performed by retrieving 1018 cases of ovarian teratomas reported in last 6 years. SPSS version 20 was used for data analysis.

Results: MCT was most frequent ovarian teratoma with frequency of $95.6 \%(\mathrm{n}=973), 2.26 \%(\mathrm{n}=23)$ being IT and $2.16 \%$ $(n=22)$ being MoT. IT were mostly seen in pediatric age group. MT in benign MCT was seen in $0.72 \%$ of MCT ( $n=7)$. Squamous cell carcinoma was most frequent malignancy $71.4 \%(n=5)$. One case of MoT also showed MT into papillary thyroid carcinoma, classic type, with frequency of MT in Mot being 4.76\% $(n=1)$. All MT in MCT had age $>30$ years which was a significant finding $(\mathrm{p}<0.001)$.

Conclusion: Ovarian masses in postmenopausal patients with suspicious radiological features, irrespective of lesional size warrant a thorough gross examination, extensive sampling and a careful microscopic evaluation.
\end{abstract}

Key words: Ovary, Teratoma, Malignant

\section{INTRODUCTION}

$\mathrm{O}$ varian teratomas are germ cell tumors (GCT) that arise from ectopic pluripotent stem cells that fail to migrate from yolk sac endoderm to the urogenital ridge during embryogenesis. They comprise elements from all three embryological germ layers i.e. endoderm, mesoderm and ectoderm. ${ }^{1}$

Teratomas include mature cystic teratomas (MCT), immature teratomas (IT) and monodermal teratomas (MoT). MCT are well differentiated relative to the germ cell layers while immature teratomas are incompletely differentiated and contain embryonic tissue along with neuroepithelium. ${ }^{2,3,4,5}$ The IT are graded from I to III on the basis of quantity of neuroepithelium. ${ }^{6,7}$ MoT are composed of a single tissue type and usually contain thyroid tissue, in which case they are referred to as struma ovarii. ${ }^{8}$ Malignancy can also arise in struma ovarii. The age of presentation of malignancy in struma ovarii is usually in the 5th decade of life, with thyroid type malignancies being the most common. ${ }^{9,10,11}$
Presence of a concomitant malignancy arising in a teratoma is a diagnostic challenge not only for clinicians but also for pathologists. The preoperative risk assessment of teratomas with malignant transformations (MT) are challenging and it is of great importance that optimal management options be selected carefully. ${ }^{12}$

We hereby discuss the morphological spectrum of ovarian teratomas reported in the last six years (January 2015-December 2020) at the Chughtai Institute of Pathology.

\section{MATERIAL AND METHODS}

After approval from Institutional Review Board, a retrospective study was performed in all histologically diagnosed cases of ovarian teratomas in females of all ages, from January 2015 to December 2020 at the Department of Histopathology, Chughtai Institute of Pathology. All diagnosed cases of MCT, IT of all grades, MoT and malignancies arising in MCT were included in the study. Specimens received unfixed or received from an outside laboratory were excluded from the study. Non-probability consecutive sampling was used. 
The data was retrieved using institutional software Nexus Pro. A total of 1018 cases of teratomas were retrieved. Clinico-pathological parameters including age, tumor size, histological type and laterality were obtained from Pathology reports.

\section{Statistical analysis:}

Data was analyzed using SPSS version 20. The mean and standard deviation were calculated for quantitative variables including age and tumor size. MT was noted in both MCT and MoT. Qualitative variables including histologic type and laterality has been presented in the form of frequencies and percentages. Effect modifiers like age and tumor size have been controlled through stratification (for MT). Post stratification Chi-Square test was applied by taking $\mathrm{P}$ value of 0.05 as significant.

\section{RESULTS}

A total of 1018 cases were included in the study. Mean age was $30.7+/-10.2$ years. $46.6 \%(n=474)$ of the cases were right sided, $37.2 \%(n=379)$ were left sided while $7.0 \%(\mathrm{n}=71)$ were bilateral (Table-1). $39.7 \%(n=404)$ of the cases were between age group of 20-29 years (Table-3). Mean size of the tumor was $8.1+/-3.6 \mathrm{~cm}$, with $60.5 \%(\mathrm{n}=616)$ cases being between 5 to $10 \mathrm{~cm}$. A total of $95.6 \%(\mathrm{n}=973)$ were MCT with $94.9 \%(\mathrm{n}=966)$ diagnosed as benign MCT (Table-2). $0.72 \%(n=7)$ of the cases showed a malignancy arising in MCT. 5 cases were of squamous cell carcinoma (71.4\%), 1 was mucinous adenocarcinoma, 1 was high grade B-cell NonHodgkin Lymphoma (NHL). Mean age of cases with malignancy arising in MCT was 45.1 years and mean size was $9.73 \mathrm{~cm}$ (Table-4). All malignancies arising in MCT had age $>30$ years with $3.05 \%$ chance of malignancy over the age of 40 years compared to overall chance of malignancy of $0.72 \%$ for all age groups. This finding was significant with a $\mathrm{P}$ value of $<0.001$ (Table-5). No correlation with size and malignancy was noted (Table-6). 2.10\% $(n=21)$ cases were diagnosed as MoT. 1 case of MoT showed papillary thyroid carcinoma arising in it, while one case was of strumal carcinoid. $2.26 \%$ $(n=23)$ were IT $(n=2$ for grade I, $n=9$ for grade II and $n=12$ for grade III). $73.9 \%(n=17)$ of IT were diagnosed in patients under 30 years of age.

\begin{tabular}{|l|l|}
\hline AGE & $30.7+/-10.2$ years \\
\hline Age (years) & \multicolumn{2}{|l|}{ SIZE } & $8.1+/-3.6 \mathrm{~cm}$ \\
\hline Size $(\mathrm{cm})$ & \multicolumn{2}{|l|}{ Frequency and percentage of laterality } \\
\hline Right & $474(46.6 \%)$ \\
\hline Left & $379(37.2 \%)$ \\
\hline Bilateral & $71(7.0 \%)$ \\
\hline Not specified & $94(9.2 \%)$ \\
\hline Different histologic subtypes \\
\hline MCT & $973(95.6 \%)$ \\
\hline G1, IT & $2(0.20 \%)$ \\
\hline G2, IT & $9(0.88 \%)$ \\
\hline G3, IT & $12(1.18 \%)$ \\
\hline MoT & $22(2.16 \%)$ \\
\hline
\end{tabular}

Table-1: Break down of results $(\mathrm{n}=1018)$

\begin{tabular}{|l|c|c|c|c|c|c|c|}
\hline \multirow{2}{*}{$\begin{array}{c}\text { Tumor } \\
\text { Size }\end{array}$} & \multicolumn{7}{|c|}{ Histologic Type } \\
\cline { 2 - 8 } & MCT & $\begin{array}{c}\text { Malignancy } \\
\text { in MCT }\end{array}$ & $\begin{array}{c}\text { G1, } \\
\text { IT }\end{array}$ & $\begin{array}{c}\text { G2, } \\
\text { IT }\end{array}$ & $\begin{array}{c}\text { G3, } \\
\text { IT }\end{array}$ & MoT & $\begin{array}{c}\text { Malignancy } \\
\text { in MoT }\end{array}$ \\
\hline$<\mathbf{5 . 0 c m}$ & 166 & 0 & 0 & 0 & 1 & 5 & 0 \\
\hline $\mathbf{5 - 1 0 . 0 c m}$ & 585 & 5 & 2 & 6 & 7 & 10 & 1 \\
\hline$>\mathbf{1 0 . 0 c m}$ & 215 & 2 & 0 & 3 & 4 & 6 & 0 \\
\hline
\end{tabular}

Table-2: Frequency of different histologic subtypes and tumor size stratification

\begin{tabular}{|l|c|c|c|c|c|c|c|}
\hline \multirow{2}{*}{$\begin{array}{c}\text { Age } \\
\text { Group }\end{array}$} & \multicolumn{7}{|c|}{ Histologic Type } \\
\cline { 2 - 9 } & MCT & $\begin{array}{c}\text { Malignancy } \\
\text { in MCT }\end{array}$ & $\begin{array}{c}\text { G1, } \\
\text { IT }\end{array}$ & $\begin{array}{c}\text { G2, } \\
\text { IT }\end{array}$ & $\begin{array}{c}\text { G3, } \\
\text { IT }\end{array}$ & MoT & $\begin{array}{c}\text { Malignancy } \\
\text { in MoT }\end{array}$ \\
\hline$<10$ years & 4 & 0 & 1 & 2 & 4 & 0 & 0 \\
\hline 10-19 years & 83 & 0 & 1 & 1 & 2 & 1 & 0 \\
\hline 20-29 years & 391 & 0 & 0 & 4 & 2 & 7 & 0 \\
\hline 30-39 years & 309 & 1 & 0 & 2 & 2 & 4 & 0 \\
\hline 40-49 years & 133 & 3 & 0 & 0 & 2 & 4 & 0 \\
\hline$>50$ years & 46 & 3 & 0 & 0 & 0 & 5 & 1 \\
\hline
\end{tabular}

Table-3: Frequency of different histologic subtypes and age group stratification

\begin{tabular}{|c|l|c|c|c|}
\hline $\begin{array}{c}\text { Sr. } \\
\text { No. }\end{array}$ & \multicolumn{1}{|c|}{ Diagnosis } & Laterality & Age & Size \\
\hline 1 & $\begin{array}{l}\text { Moderately differentiated } \\
\text { Squamous cell carcinoma }\end{array}$ & Right & 42 & $5.0 \mathrm{~cm}$ \\
\hline 2 & High Grade B-cell NHL & Right & 40 & $8.2 \mathrm{~cm}$ \\
\hline 3 & $\begin{array}{l}\text { Moderately Differentiated } \\
\text { Squamous cell carcinoma }\end{array}$ & Left & 53 & $6.9 \mathrm{~cm}$ \\
\hline 4 & $\begin{array}{l}\text { Poorly Differentiated } \\
\text { Squamous cell carcinoma }\end{array}$ & Right & 55 & $18.0 \mathrm{~cm}$ \\
\hline 5 & $\begin{array}{l}\text { Moderately differentiated } \\
\text { squamous cell carcinoma }\end{array}$ & Left & 40 & $8.0 \mathrm{~cm}$ \\
\hline 6 & $\begin{array}{l}\text { Well Differentiated } \\
\text { Squamous Cell Carcinoma }\end{array}$ & Right & 51 & $12.0 \mathrm{~cm}$ \\
\hline 7 & Mucinous Adenocarcinoma & Left & 35 & 10.0 \\
\hline 8 & $\begin{array}{l}\text { Papillary Thyroid } \\
\text { Carcinoma in Struma Ovarii }\end{array}$ & Left & 55 & $6.5 \mathrm{~cm}$ \\
\hline
\end{tabular}

Table-4: Malignancies Arising in Teratomas 


\begin{tabular}{|c|c|c|c|}
\hline Age group & $\begin{array}{c}\text { Benign } \\
\text { MCT }\end{array}$ & $\begin{array}{c}\text { Malignancies } \\
\text { in MCT }\end{array}$ & \\
\hline$<40$ years & 787 & 1 & 788 \\
\hline$\geq 40$ years & 179 & 6 & 185 \\
\hline & 966 & 7 & 973 (Grand total) \\
\hline \multicolumn{4}{|l}{$\mathrm{P}=<0.00001$ (Significant $=<0.05$ ) } \\
\hline
\end{tabular}

Table-5: Age Group and Malignancies

\begin{tabular}{|l|c|c|c|}
\hline Size & $\begin{array}{c}\text { Benign } \\
\text { MCT }\end{array}$ & $\begin{array}{c}\text { Malignancies } \\
\text { in MCT }\end{array}$ & TOTAL \\
\hline$<\mathbf{5 . 0 c m}$ & 166 & 0 & 166 \\
\hline $\mathbf{5 - 1 0 . 0 c m}$ & 585 & 5 & 590 \\
\hline$>\mathbf{1 0 . 0 c m}$ & 215 & 2 & 217 \\
\hline TOTAL & 966 & 7 & $\begin{array}{c}973 \\
\text { (Grand total) }\end{array}$ \\
\hline $\mathbf{P = 0 . 1 6}$ (Significant $=<\mathbf{0 . 0 5}$ ) \\
\hline
\end{tabular}

Table-6: Size correlation and Malignancies in MCT

\section{DISCUSSION}

Teratomas are one of the most common germ cell tumors with mature or immature histological features. MCT are composed of well differentiated derivations from at least two of the three germ layers (ectoderm, endoderm and mesoderm) and are benign in nature whereas IT, are rare tumors comprising incompletely differentiated tissue found either in pure form or as a component of a mixed germ cell tumor and occurs essentially during the first two decades of life. ${ }^{1,2,3,4,5}$ They clinically have a malignant behavior and are characterized by the presence of immature (neuroectodermal) tissue. Immature teratomas are typically larger than mature cystic teratomas and are graded as I to III according to the percentage of neuro epitelium. The higher the grade of the mass, the more aggressive behavior is expected. ${ }^{5,6}$ Monodermal teratomas, as the name indicates, are composed predominantly or solely of one tissue type. There are three main types of ovarian monodermal tumors: Struma ovarii, ovarian carcinoid tumors and neural tumors. Struma ovarii is the commonest monodermal teratoma ${ }^{8}$ and has an excellent prognosis until malignant transformation occurs. Malignant transformation most commonly occurs in the form of papillary thyroid carcinoma (PTC), however rarely follicular carcinoma, poorly differentiated carcinoma and anaplastic carcinoma can also arise in this tumor type. , $^{910,11}$

In this study we determined the morphological spectrum of more than a thousand ovarian teratomas $(n=1018)$ diagnosed in a span of six years at Chughtais Institute of Pathology, Lahore. Benign MCT (Fig-1A) were most frequent, comprising $94.9 \%(n=966)$ of total cases. Mean age of the patients was 30.7 years with most of the cases $(37.4 \%)$ presenting within the age group of 20-29 years. These findings are consistent with a study conducted by Trabzonlu et al. in which mean age of the patients 34.5 years. ${ }^{13}$ Average size of the teratomas was $8.01 \mathrm{~cm}$ with $59.8 \%$ of the cases being in between $5-10 \mathrm{~cm}$. These findings are partially consistent with a study performed by Rathore et $\mathrm{al}^{14}$ and Trabzonlu et al. with an average size of $7.60 \mathrm{~cm}$ and $8.37 \mathrm{~cm}$ respectively. In our study majority of the teratomas were right sided (46.6\%) with $7 \%$ being bilateral. Right side predominance has also been reported by Ismail et al. and Chun et al. ${ }^{15,16}$ However, a study conducted by Khan et al from Peshawar showed left sided predominance. ${ }^{17}$

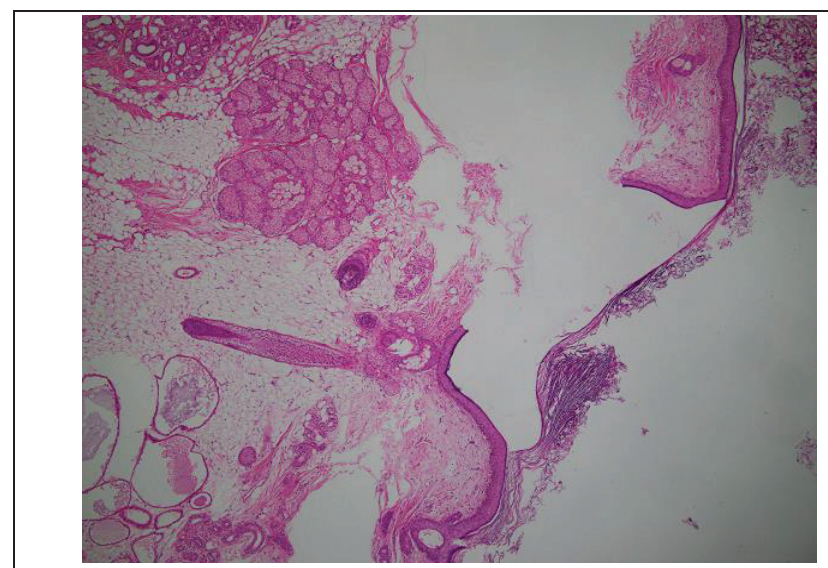

A. Benign mature cystic teratoma

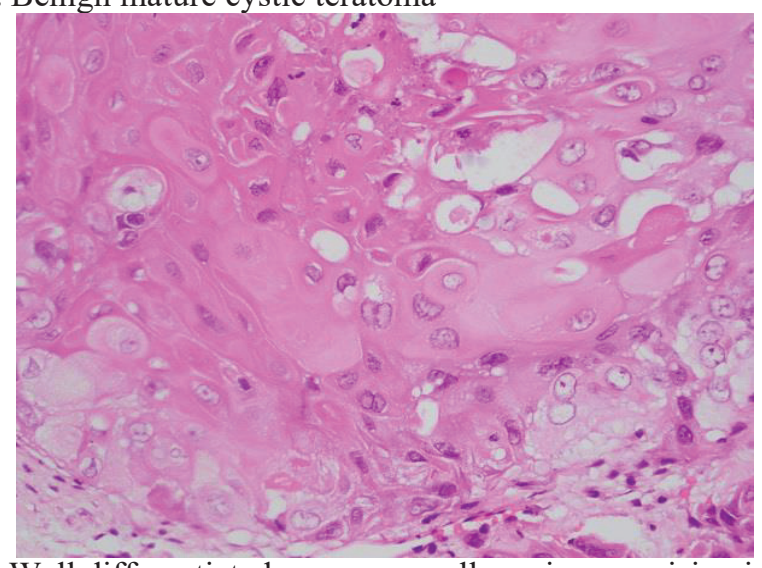

B. Well differentiated squamous cell carcinoma arising in mature cystic teratoma

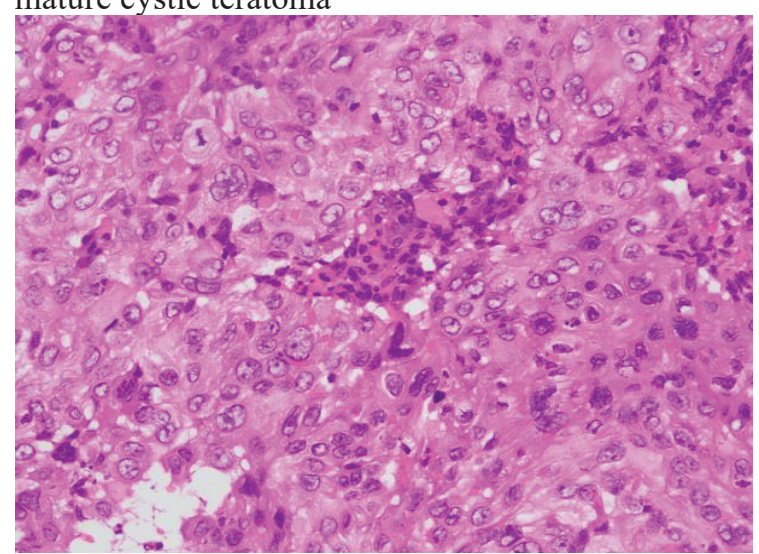

C. Moderately differentiated squamous cell carcinoma 


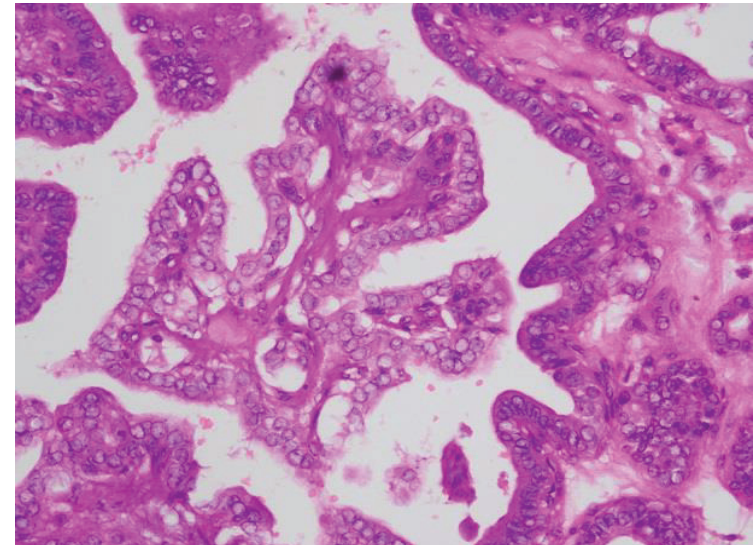

D. Papillary thyroid carcinoma arising in Monodermal Teratoma

Fig-1: Different Morphological Spectrum in Teratomas.

Malignant transformation (MT) in a MCT is a known phenomenon but is a rare occurrence. Numerous studies have demonstrated a frequency of MT in MCT to be not more than $2 \%$ and usually effecting patients in the post-menopausal age group. ${ }^{8,9,12} \mathrm{~A}$ variety of malignant transformations are documented till date, the commonest being squamous cell carcinomas (88.3\%), followed by adenocarcinoma, fibrosarcoma, rhabdomyosarcoma, malignant melanoma, urothelial carcinoma, adenosquamous carcinoma, endometrioid carcinoma, carcinosarcoma and papillary thyroid carcinoma. ${ }^{18-25}$ In our study, malignancy arising in $\mathrm{MCT}$, was seen in 7 cases, which comprises $0.72 \%$ of all included cases. A study conducted by Ud Din $\mathrm{N}$ et al. showed frequency of epithelial malignancies arising in MCT as $1.9 \% .{ }^{12}$ Another study conducted by Ulker et al. also showed malignant transformation in $1.9 \%$ of the total cases. ${ }^{20}$ MT was mostly seen in patients of peri-menopausal and postmenopausal age group with 6 cases out of a total of 7 being $\geq 40$ years of age ( $85.8 \%$ ). The mean age in our study for these MT cases was 45.1 years compared with 30.7 years for all cases of MCT. This difference in age between benign MCT and MT in MCT was statistically significant with a $p$ value of $<0.001$. Our findings are consistent with these national and international studies. The average size of the teratomas with MT in MCT was $9.73 \mathrm{~cm}$. There was no significant correlation between sizes of MT in MCT and benign MCT. Previous studies have identified some risk factors for malignant transformations in MCTs; these factors broadly include older age at presentation, post-menopausal status, and raised serum tumor markers; especially serum CA-125 levels. Other findings consistently seen in patients with MT in MCT include larger tumor masses with grossly visible areas of hemorrhage and necrosis. ${ }^{12}$ Our findings are consistent with the general notion of a larger lesional size in case of MT in MCT as compared to benign MCT. ${ }^{12,13,21}$

Most common malignancy reported to arise within the MCT is squamous cell carcinoma and it usually comprises more than $70 \%$ of the malignancies..$^{12,13,20-23,26}$ In our study, squamous cell carcinoma was the most frequent MT in MCT comprising $71.4 \% \quad(n=5)$ of all cases showing malignant transformation (Fig-1B and 1C). One case was of mucinous adenocarcinoma while another case was of a high grade B-cell non-hodgkin lymphoma (NHL). Our case with a mucinous adenocarcinoma arising in MCT of the ovary was confirmed to have a germ cell origin confirmed by its reactivity for CK-20 immunohistochemical (IHC) stain and negativity for CK-7 IHC stain. ${ }^{27,28}$ Ovarian B cell lymphomas are very rare and usually are of primary ovarian origin, without any associated teratoma. The high grade B-cell NHL included in our study was associated with an ovarian MCT. ${ }^{29}$

Overall frequency of immature teratomas was $2.26 \%(n=23)$ with mean age of 20.8 years, mean size of $8.62 \mathrm{~cm}$ and were right sided predominantly $(\mathrm{n}=12,52.2 \%)$. Most of immature teratomas were of grade $3(\mathrm{n}=12,52.2 \%)$. A study conducted by Gallion et al. also showed majority of cases of immature teratomas being diagnosed in patients under 25 years of age. ${ }^{30}$ A study conducted in India showed a median age of 19 years. In this study, Grade II (IT) were most frequent, comprising $46 \%$ of the cases while grade III (IT) comprised $25 \%$ of the cases. ${ }^{5}$ These results were in contrast to our findings in which grade III (ITs) were the most frequent.

22 MoT were included in the study with an average age of 36.3 years and a mean size of $7.29 \mathrm{~cm} .1$ case (4.55\%) showed papillary thyroid carcinoma (PTC) arising in the background of MoT (Fig-1D). The age of that patient was 55 years with tumor size being $6.50 \mathrm{~cm}$. One case was of strumal carcinoid $(4.55 \%)$. The frequency of PTC and strumal carcinoid arising in MoT is reported to be in between $5 \%$ to $10 \%{ }^{31,32,33}$

\section{CONCLUSION}

Ovarian teratomas have a diverse morphological spectrum including the mature cystic, immature and monodermal subtypes. Malignancies arising in each one of these subtypes is a rare phenomenon. However, ovarian masses in postmenopausal patients with suspicious radiological features, 
irrespective of lesional size warrant a thorough gross examination with extensive sampling of the specimen and a careful microscopic evaluation. Correlation with serum tumor markers and intraoperative consultation in such cases should be sought to determine the best modality of treatment for these patients.

\section{REFERENCES}

1. Outwater EK, Siegelman ES, Hunt JL. Ovarian teratomas: tumor types and imaging characteristics. Radiographics. 2001 Mar; 21(2):475-90.

2. Peterson CM, Buckley C, Holley S, Menias CO. Teratomas: a multimodality review. Current problems in Diagnostic Radiology. 2012 Nov 1; 41(6):210-9.

3. Wetherell D, Weerakoon M, Williams D, Beharry BK, Sliwinski A, Ow D, Manya K, Bolton DM, Lawrentschuk N. Mature and immature teratoma: A review of pathological characteristics and treatment options. Med Surg Urol. 2014; 3(124):2.

4. Abiko K, Mandai M, Hamanishi J, Matsumura N, Baba T, Horiuchi A, Mikami Y, Yoshioka S, Wakasa $\mathrm{T}$, Shiozawa T, Konishi I. Oct4 expression in immature teratoma of the ovary: relevance to histologic grade and degree of differentiation. The American Journal of Surgical Pathology. 2010 Dec 1; 34(12):1842-8.

5. Deodhar KK, Suryawanshi P, Shah M, Rekhi B, Chinoy RF. Immature teratoma of the ovary: a clinicopathological study of 28 cases. Indian journal of pathology and microbiology.2011Oct 1;54(4):730.

6. Cecchetto G. Gonadal germ cell tumors in children and adolescents. Journal of Indian Association of Pediatric Surgeons. 2014 Oct; 19(4):189.

7. Schneider DT, Terenziani M, Cecchetto G, Olson TA. Gonadal and extragonadal germ cell tumors, sex cord stromal and rare gonadal tumors. In Rare tumors in children and adolescents 2012 (pp. 327402). Springer Berlin Heidelberg.

8. Kondi-Pafiti A, Mavrigiannaki P, Grigoriadis $\mathrm{CH}$, Kontogianni-Katsarou K, Mellou A, Kleanthis CK, Liapis A. Monodermal teratomas (strumaovarii). Clinicopathological characteristics of 11 cases and literature review. European Journal of Gynaecological Oncology. 2011 Jan 1; 32(6):657.

9. Salman WD, Singh M, Twaij Z. A case of papillary thyroid carcinoma in strumaovarii and review of the literature. Pathology Research International. 2010 Aug 2;2010.

10. Khunamornpong S, Settakorn J, Sukpan K, Suprasert P, Siriaunkgul S. Poorly Differentiated Thyroid Carcinoma Arising in Struma Ovarii. Case reports in pathology. 2015.

11. Goffredo P, Sawka AM, Pura J, Adam MA, Roman SA, Sosa JA. Malignant strumaovarii: a populationlevel analysis of a large series of 68 patients. Thyroid. 2015 Feb 1; 25(2):211-5.
12. Ud Din N, Minhas K, Arshad S, Kayani N. Epithelial Malignancies Arising in Ovarian Mature Cystic Teratoma: A Series of 26 Cases. J CytolHistol S. 2016; 5 .

13. Trabzonlu L, Durmaz G, Vural C, Muezzinoglu B, Corakci A. Malignant tumors associated with ovarian mature teratoma: a single institution experience. Pathology-Research and Practice. 2017 May 1; 213(5):518-21.

14. Rathore R, Sharma S, Agarwal S. Malignant transformation in mature cystic teratoma of the ovary: a retrospective study of eight cases and review of literature. Przegladmenopauzalny= Menopause review. 2018 Jun; 17(2):63.

15. Ismail SR. An evaluation of the incidence of rightsided ovarian cystic teratoma visualized on sonograms. JdiagnostMedsono.2005Jul;21(4):336-42

16. Chun S, Jeon GH, Cho HJ, Ji YI. Comparison between incidence of right-and left-sided ovarian cystic teratomas. Journal of Reproductive Endocrinology. 2012 Apr 1; 4(1):43-8.

17. Khan MM, Sharif N, Ahmad S. Morphological spectrum of mature ovarian teratoma. Gomal J Med Sci 2014; 12:76-80.

18. Bal A, Mohan H, Singh SB, Sehgal A. Malignant transformation in mature cystic teratoma of the ovary: report of five cases and review of the literature. Archives of Gynecology and obstetrics. 2007 Mar; 275(3):179-82.

19. Ulker V, Numanoglu C, Akbayir O, Akyol A, Tuncel A, Akca A, Aydin O. Malignant transformation arising from mature cystic teratoma of the ovary: a report of six cases. J Obs Gynaecol Res. 2012 May; 38(5):849-53.

20. Hackethal A, Brueggmann D, Bohlmann MK, Franke FE, Tinneberg HR, Münstedt K. Squamouscell carcinoma in mature cystic teratoma of the ovary: systematic review and analysis of published data. The Lancet Oncology.2008 Dec 1;9(12):117380

21. M.M. Desouki, O. Fadare, B.K. Chamberlain, N. Shakir, A. Kanbour-Shakir, Malignancy associated with ovarian teratomas: frequency, histotypes, and diagnostic accuracy of intraoperative consultation, Ann. Diagn. Pathol. 19(June (3)) (2015) 103-106.

22. L. Dos Santos, E. Mok, A. Iasonos, K. Park, R.A. Soslow, C. Aghajanian, et al., Squamous cell carcinoma arising in mature cystic teratoma of the ovary: acase series and review of the literature, Gynecol. Oncol. 105 (May (2)) (2007)321-324.

23. M. Sakuma, T. Otsuki, K. Yoshinaga, H. Utsunomiya, S. Nagase, T. Takano, et al.,Malignant transformation arising from mature cystic teratoma of the ovary: aretrospective study of 20 cases, Int. J. Gynecol. Cancer 20 (July (5)) (2010)766-771) Malignancy in post-menopausal patient.

24. Kudva R, Ayachit GS, Ayachit A. Malignant melanoma arising in an ovarian mature cystic teratoma-a rare entity. Journal of Clinical and Diagnostic Research: JCDR. 2015 Apr; 9(4):ED14. 
25. Sanz-Baro R, Alvarez G, Fernández-Aceñero MJ, Di Fiore HA. Ovarian Rhabdomyosarcoma Arising from Mature Cystic Teratoma.

26. Sharma IVY, Saikia CJ. Squamous Cell Carcinoma Arising in Mature Cystic Teratoma - A Rare Case Report. Paripex-Indian J Res. 2015; 4:168-9.

27. Kerr SE, Flotte AB, McFalls MJ, Vrana JA, Halling $\mathrm{KC}$, Bell DA. Matching maternal isodisomy in mucinous carcinomas and associated ovarian teratomas provides evidence of germ cell derivation for some mucinous ovarian tumors. The American Journal of Surgical Pathology. 2013 Aug 1; 37(8):1229-35.

28. Snir OL, Buza N, Hui P. Mucinous epithelial tumours arising from ovarian mature teratomas: a tissue genotyping study. Histopathology. 2016 Sep; 69(3):383-92.

29. Afzal S, Zaman S. High Grade B-Cell NonHodgkin's Lymphoma Arising in a Mature Cystic Teratoma of The Ovary: A Case Report. International Journal of molecular and Cellular medicine. 2017; 6(4):239.

30. Gallion H, van Nagell JR, Donaldson ES, Hanson $\mathrm{MB}$, Powell DF. Immature teratoma of the ovary. American Journal of Obstetrics and Gynecology. 1983 Jun 15; 146(4):361-5.

31. Szczepanek-Parulska E, Pioch A, Cyranska-Chyrek E, Wolinski K, Jarmołowska-Jurczyszyn D, JanickaJedynska M, Majewski P, Zabel M, Ruchala M. The role of immunohistochemical examination in diagnosis of papillary thyroid cancer in strumaovarii. Folia histochemicaetcytobiologica. 2019;57(1):35-42

32. Wei S, Baloch ZW, LiVolsi VA. Pathology of strumaovarii: a report of 96 cases. Endocrine Pathology. 2015 Dec; 26(4):342-8.

33. Nishida M, Kawano Y, Yuge A, Nasu K, Matsumoto H, Narahara H. Three cases of immature teratoma diagnosed after laparoscopic operation. Clinical medicine insights. Case reports. 2014; 7:91-4.

\section{The Authors:}

Dr. Fatima Khalid

Consultant Histopathologist,

Department of Histopathology,

Chughtai Institute of Pathology, Lahore.

Dr. Sameen Afzal

Consultant Histopathologist,

Department of Histopathology,

Chughtai Institute of Pathology, Lahore.

Dr. Ghazi Zafar

Consultant Histopathologist,

Department of Histopathology,

Chughtai Institute of Pathology, Lahore.

Dr. Anila Chughtai

Consultant Histopathologist,

Department of Histopathology,

Chughtai Institute of Pathology, Lahore.

Dr. Samina Zaman

Consultant Histopathologist,

Department of Histopathology,

Chughtai Institute of Pathology, Lahore.

Dr. Akhtar Sohail Chughtai

Consultant Histopathologist,

Department of Histopathology,

Chughtai Institute of Pathology, Lahore.

\section{Corresponding Author:}

Name: Dr. Fatima Khalid

Consultant Histopathologist,

Department of Histopathology,

Chughtai Institute of Pathology, Lahore.

E-mail: faatimaa1988@gmail.com 